\title{
Exploring Cultural Employment: The Case of Turkey
}

\author{
SELDA Dudu ${ }^{1}$ \\ Received: 05.07.2020; Revised: 04.11.2020; Accepted: 11.11.2020
}

\begin{abstract}
Culture is a core element shaping human behaviour. Cultural activities have existed from the beginning of time and gradually transformed into an industry. As a result, today, the existence of the cultural industry and cultural workers is quite clear. The purpose of this study is to outline the core concepts of cultural employment and to explore the structure of cultural employment in Turkey by using primary data obtained by an online survey conducted among Turkish cultural workers in 2016. This study contributes to the literature by examining the atypical work arrangements of cultural workers in Turkey. Our findings confirm that cultural workers in Turkey are at risk of in-work poverty, and their earnings differ according to gender, contract type, employment and employee types. We found in this study that the middle-aged cultural workers working with permanent contracts in state subsidized intuitions earn more. This study highlights the need for systematic studies on cultural employment and the implementation of a comprehensive policy to protect the rights of cultural workers in Turkey.
\end{abstract}

JEL codes: J21, J80, J81

Keywords: Cultural Employment, Cultural Industry, Cultural Workers, Turkey, In-work Poverty, Atypical Work

\section{Introduction}

Culture surrounds us in every area of our daily lives and relationships with others. People create culture through games (Huizinga, 2006), ideas and behaviours, crafts, beliefs, customs (Malinowski, 1960), symbols, language, values and norms (Eagleton, 2016). Culture is also to be found

${ }^{1} \mathrm{PhD}$ Candidate, Program in Business, Economics and Social Sciences, University of Seville, Seville, Spain. (e-mail: selda@dudu.gen.tr).

2 Acknowledgement: I would like to thank Prof Dr Teresa Rojo from the University of Seville for her supervision and Meltem Cumbul for her support to reach the survey participants during her presidency in the Actors' Union of Turkey. in ways of thinking and acting, including the material objects (such as a table or a chair) and the non-material elements (such as art or Zen) (Macionis, 2010) that together form a people's shared way of life (Eagleton, 2016; Highmore, 2016; Macionis, 2010; Jenks, 1993); it encompasses everything we learn to live our lives in the social groups to which we belong (Tischler, 2011). Thus, culture differentiates humans from other creatures (Jenks, 1993) and carries the following features: integration, historicity, uniformity, causality, significance and values and relativism (Kroeber \& Kluckhohn, 1952).

Creativity is essential for the genesis of cul- 
ture. However, every action or item could be seen to be creative, so creativity alone is not sufficient to create a culture. Besides the element of human creativity, the presence of symbolic messages (UNCTAD, 2008; Galloway \& Dunlop, 2007) and intellectual property (Eagleton, 2016; UNCTAD, 2008; Galloway \& Dunlop, 2007; Jenks, 1993) are vital characteristics of culture. Hence, cultural production also includes these three features. The cultural products may be music, films, theatrical plays, city museums, printed literature, designed materials, fashion, places or many other things, even cities. These products are created in theatres, radios, concert halls, bars, cinemas, television and even on the streets. During cultural production, workers experience atypical working conditions; thus, cultural employment is closely linked to the limits of atypical work.

In Turkey, since few studies (Hoş, 2018; Şen, 2017; Lena, 2016) examine cultural employment, there is a need for systematic studies in this area (Şen, 2017). This study contributes to the literature by examining the atypical working arrangements of cultural workers in Turkey. The purpose of this study is to outline the core concepts of cultural employment and to explore the structure of cultural employment in Turkey. The study presents data on the issues surrounding the employment status of cultural workers in Turkey. The data was acquired through an online survey of cultural workers in Turkey.

The findings of this study highlight the relationship between the income of cultural workers and their working arrangements, which suggests the existence of in-work poverty among cultural workers. This study identifies a need for more systematic studies about cultural employment and the implementation of a comprehensive policy to protect the rights of cultural workers in Turkey. To that end, this study reviews the existing literature. It then shares the findings of the survey about cultural employment in Turkey and discusses these findings before presenting its conclusion.

\section{Literature review}

This section presents the literature on the structure of cultural employment in Turkey after discussing the core concepts related to cultural employment, such as the cultural industry and cultural workers. The section then focuses specifically on the literature about cultural employment in Turkey.

\subsection{Cultural Industry}

Today, culture is adopting industrial production strategies under the concept of the service sector; but how do we call it specifically? In the literature, the analyses of 'how cultural goods are produced and disseminated in modern economies and societies' (Hesmondhalgh, 2008), use two different terms: cultural industries and creative industries.

The idea of the cultural industry is based on standardisation, meeting the needs of everyone who wants to own artwork. Millions of copies of cultural goods are made and distributed rapidly to every corner of the globe, using technology which allows the reproduction of cultural products (Benjamin, 2008). For example, a cathedral is built as an immovable structure but taking a photograph of it turns the cathedral, a massive object, into an object that can move anywhere. In other words, an artwork is transformed into another artwork again and again. Therefore, 'all mass culture under monopoly is identical' (Horkheimer \& Adorno, 2002). Cultural goods and services are converted into commodities and, thus, culture created its own industry. Hence, 'the whole world is passed through the filter of the culture industry' (Horkheimer \& Adorno, 2002).

The cultural industry differs in four aspects from other industries in the economy: output, industry structure, the behaviour of firms and employment. The output of the cultural industry shares more characteristics with public goods than private goods because cultural goods and services are merit goods and have cultural value. Therefore, the structure of the cultural industry contains 
a significant number of not-for-profit enterprises alongside commercial firms and public institutions. The behaviours of the firms tend to produce compliance not only with the needs of the market but also the cultural values of the goods and services. The employment structure is complicated because it includes both artistic/aesthetic jobs and nonartistic/non-aesthetic jobs (Throsby, 2008). The term 'creative industry', in contrast, originated in the mid-1990s, starting with the concepts of the creative city and creative clusters, which developed their festivals, major museums and theatre complexes in the culture-led urban regeneration boom' (Hesmondhalgh, 2008). The phrase has been developed to strengthen the protection of intellectual property and taking the public support for the training of creative workers by departing from the UK's Department of Culture, Media and Sport (DCMS) (Throsby, 2008). To satisfy the needs of the market and create economic value (Primorac, 2014; Hesmondhalgh, 2008; Throsby, 2008), creative industry is a broader term, covering not only copyright related to intellectual property protection, but also electronic, chemical and pharmaceutical patents. Thus, the term 'creative industry' was shaped by globalisation and a neoliberal understanding (Hesmondhalgh, 2008).

The two terms - cultural industries and creative industries - were merged by the Beijing Party Committee in The People's Republic of China in 2005 to form the 'cultural and creative industries' (Hesmondhalgh, 2008), a term used by other authors since (Primorac, 2014; O'Connor, 2011).

In the studies about Turkey, there is no consensus about the usage of the term. Some authors (Demir, 2018; Erataş, Alptekin, \& Uysal, 2013; Abadan-Unat, 1983) prefer the term 'cultural industry' while others (Kepenek, 2015; Yörük, 2018; Cetiz, 2017; Erkayhan, 2015; Demir, 2018; Şimşek \& Güven, 2015; Hocaoğlu, 2015) use the term 'creative industry'. Only a few researchers (Kaymas, 2019; Şen, 2017) prefer the term 'cultural and creative industries'.

This study prefers to use the term 'cultural industry' which is interested in the creation of culture rather than the creative industry, which includes creating new patents. The cultural industry is the industry in which cultural workers produce cultural products. Since creativity can cover everything, it is hard to analyse all goods and services related to creativity. Moreover, the concept of creativity is extended so widely (Throsby, 2008) that there is little linking the creation of a new pharmaceutical formula and a new drama, except that both are creative.

The cultural industry contributes significantly to national income in Turkey. Şen (2017) examined the cultural industry of Turkey in 2015 to estimate the size of its contribution to national income and concluded that cultural consumption in 2015 was 47.64 billion USD, equivalent to $6.4 \%$ of Turkish national income. Sen (2017) also found there to be a lack of systematic studies on cultural employment in Turkey and suggested that the data collection process for the cultural sector should be standardised according to European Union (EU) standards.

The cultural industry in Turkey has increased its trade capacity by years. Turkey's global exports of cultural products exceeded 4 billion Euros in 2015 and 2016. In comparison, imports of cultural products have only been around 750 million Euros (see Figure 1). (Eurostat, 2020b) data suggests that cultural production in Turkey has a comparative advantage.

Since 2015, Turkey has been losing this advantage as exports of cultural goods have followed a downward trend, affecting the cultural industry negatively and representing a possible cause of job losses. There is, therefore, a need to take precautionary action.

\subsection{Cultural Workers}

The constitution of the Turkish Republic states that the artistic activities and artists fall under the protection of the state, and the necessary measures to protect, evaluate, 


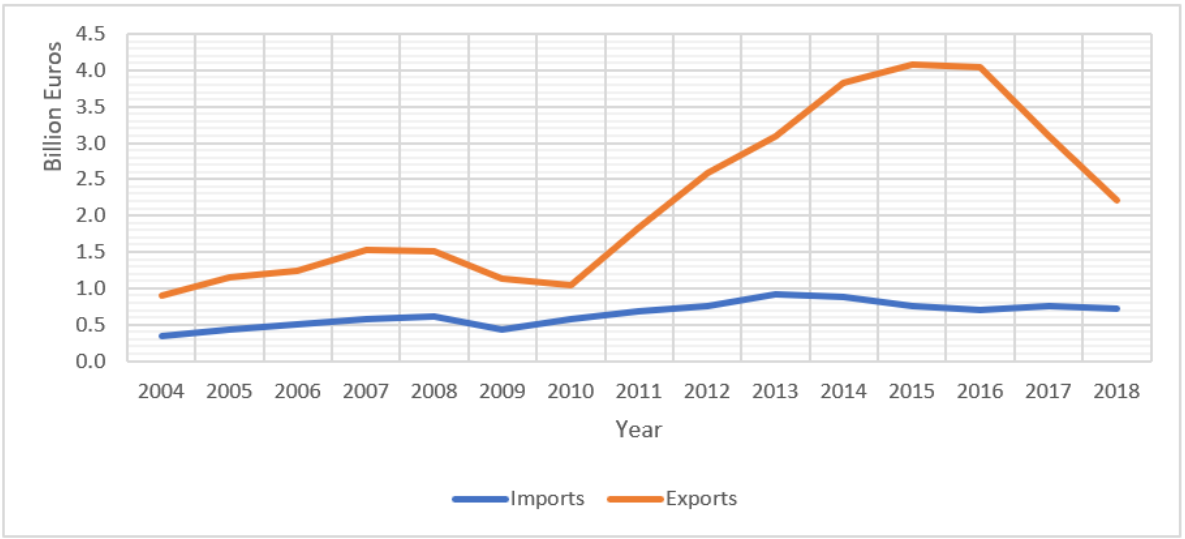

Figure 1: Turkey's Trade in Cultural Goods by Product with All Around the World Source: (Eurostat, 2020b)

support and spread art and artists are taken by the state (Constitution of The Republic of Turkey, 1982). However, what constitutes artists or cultural art workers is not clearly defined by the cultural institutions in Turkey, nor the constitution, nor any laws.

For the definition of artists, Throsby (1992) divides artists into initial creative artists (such as writers, visual artists, craftspeople and composers) and performing artists (such as actors, dancers and musicians). However, those who are not artists but who are also cultural workers, such as technicians, public relations managers and box office workers should be added to Throsby's description because cultural production is based on collective work. For example, even though the initial creative artists and performing artists may create a play, there is no audience without the box office staff. Similarly, a painter needs an art gallery and art dealers to sell their pictures. All these workers are included within the cultural industry.

Casey (1999) adopts a broader definition, listing three types of cultural worker: (1) workers who have artistic occupations within the cultural industry, such as an actor working in a theatre company, (2) workers who do not have an artistic occupation but work in the cultural industry such as a technician working in a museum, and (3) workers who have artistic occupations but work outside the cultural industry such as a musician working in a bar (Feist, 2000; Van Liemt, 2014). Thus, these three types of culture workers constitute the cultural sector. The definition by Casey (1999) is also approved by (Eurostat, 2019a). Cultural workers are those professional workers who earn money and expend effort in contributing to the creation of culture. Some Turkish studies (Artun, 2014; Abadan-Unat, 1983) use the term 'cultural workers' to mean workers who produce cultural productions.

Artun (2014) treats the efforts of cultural workers as art labour, which involves the concept of immaterial labour, based on the ideas of the Italian Autonomists. Lazzarato (1996) states that immaterial labour "produces the informational and cultural content of the commodity'. All outputs of the production of services are produced by immaterial labour, including cultural products which consist of ideas, symbols, codes, texts, language figures or images (Hardt \& Negri, 2000b, 2000a). Cultural workers, especially artists, expend their effort mostly in affective and emotional labour, which are both types of immaterial labour. Affective labour is the creation and manipulation of emotions and requires human contact and interaction (Hardt \& Negri, 2000b, 2000a; Hardt, 1999); for example, cultural workers put affective labour into writing a poem or composing a song. Emotional labour is the management of feelings by alienating oneself from an aspect of the 
self in order to perform a task (Hochschild, 1983); for example, actors distance themselves from personal feelings and adopt those required for their roles in a drama.

Cultural workers are identified by classifying cultural occupations. There are two wellknown classifications in the scope of cultural activities and cultural occupations: NACE (Statistical Classification of Economic Activities in the European Community Rev.2) and ISCO 08 (International Standard Classification of Occupations 2008) (see Table 1). While NACE is a four-digit classification system, NACE Rev. 2 is the revised two-digit version, with sub-digits, which has been implemented in the EU since 2007. However, Turkey does not collect the data according to these standards for the Household Labour Force Surveys, but considers only the two main digits, ignoring the sub-digits. Similarly, although ISCO 08 is a four-digit classification system, Turkey regards only two digits denoting occupations in collecting data. Since Turkey does not fully use NACE Rev. 2 and ISCO 08 for data collection, this article benefits from the models used in the creative industry to depict clearly the cultural industry in Turkey. These models are the UK DMCS Model, the Symbolic Text Model, the Concentric Circles Model and the WIPO (World Intellectual Property Organization) Copyright Model (UNCTAD, 2008). Each model uses a different classification of the cultural industries (see Table 2). This article, especially in the survey, aligns with the UK DMCS Model since its definition is holistic. These models are helpful in standardising cultural occupations. However, identifying cultural workers remains a challenge because self-educated workers are common in this industry, unlike others. A model in Finland uses four categories to identify artists: (1) self-definition, (2) definition based on production, (3) definition of the artist by the society at large and (4) definition by peers (Mitchell \& Karttunen, 1992). This Finnish model is easy to adopt for cultural workers, although it may be necessary to provide evi- dence from two of the four categories because self-definition without any proof may not always give an accurate picture.

Some cultural occupations in Turkey, such as architects, already have professional chambers and associations: as of 2020, there are 21 different professional associations of which cultural workers can be a member (Ministry of Culture and Tourism of Turkey, 2012). However, these chambers and associations face challenges including low membership density - there was a sharp decrease from $20 \%$ to $9.2 \%$ in $1999-2019$ in Turkey (OECD, 2019), low participation rate in activities (Çaha, 2012) and political pressure to the extent that the International Trade Union Confederation (ITUC, 2016, 2018) listed Turkey among the ten worst countries for workers globally in 2016 and 2018 because members of some unions are arrested systematically. Other challenges related to Turkey's labour market are a high unemployment rate, a high informal employment rate, a high under-employment rate (an increase in part-time and on-demand working) and an increase in subcontracting practices (Gerşil \& Aracı, 2006).

\subsection{Cultural Employment}

The working arrangements of cultural workers are atypical, including flexible work arrangements, part-time work, temporary work and self-employment (Eurofound, 2017; Mitropoulos, 2014; Nienhueser, 2005). Cultural workers are predominantly freelance or self-employed, hold multiple jobs at the same time (Benhamou, 2011; Towse, 2010; Hesmondhalgh, 2008) and have irregular and short-term jobs due to the project-based nature of their work (Umney \& Kretsos, 2014; Hodgson \& Briand, 2013; Benhamou, 2011; Towse, 2010; Hesmondhalgh, 2008). Their portfolio career path leads to income insecurity (Eikhof \& York, 2016; Benhamou, 2011; Towse, 2010; Hesmondhalgh, 2008); they have very little job protection and uncertain career paths, and unpaid work is typical in the sector (Siebert \& Wilson, 
Table 1: NACE Rev. 2 and ISCO Codes related to Cultural Workers

NACE Rev. 2 (Statistical Classification of ISCO 08 (International Standard Classification Economic Activities in the European Community of Occupations 2008)

Rev.2)

\begin{tabular}{|c|c|}
\hline $\begin{array}{l}18 \text { Printing and reproduction of recorded } \\
\text { media }\end{array}$ & $\begin{array}{l}216 \text { Architects, planners, surveyors and } \\
\text { designers }\end{array}$ \\
\hline 32.2 Manufacture of musical instruments & 2353 Other language teachers \\
\hline 58.1 Publishing of books, periodicals and other & 2354 Other music teachers \\
\hline publishing activities & 2355 Other art teachers \\
\hline 59 Motion picture, video, and television & 262 Librarians, archivists and curators \\
\hline programme production, sound recording & 264 Authors, journalists and linguists \\
\hline and music publishing activities & 265 Creative and performing artists \\
\hline 60 Programming and broadcasting activities & 3431 Photographers \\
\hline 74.1 Specialised design activities & 3432 Interior designers and decorators \\
\hline 74.2 Photographic activities & 3433 Gallery, museum, and library technicians \\
\hline 74.3 Translation and interpretation activities & 3435 Other artistic and cultural associate \\
\hline 90 Creative, arts and entertainment activities & professionals \\
\hline 91 Libraries, archives, museums, and other cul- & $\mathbf{3 5 2 1}$ Broadcasting and audio-visual technicians \\
\hline
\end{tabular}
tural activities

4411 Library clerks

7312 Musical instrument makers and tuners

7313 Jewellery and precious-metal workers

7314 Potters and related workers

7315 Glassmakers, cutters, grinders and finishers

7316 Signwriters, decorative painters, engravers and etchers

7317 Handicraft workers in wood, basketry and related materials

7318 Handicraft workers in textile, leather and related materials

7319 Handicraft workers not elsewhere classified

Source: Eurostat, 2019a

2013; Benhamou, 2011; Towse, 2010; Hesmondhalgh, 2008). Intermittent work is common in cultural employment (Karaca, 2017; Peksan \& Tosun, 2014); for example, in television series and theatres, there is a season finale followed by a few months' break, after which the work picks up again. During these months, however, producers do not pay social security premiums for cultural workers. Moreover, earnings tend to be lower than in other industries (Lena, 2016; Benhamou, 2011; Towse, 2010; Hesmondhalgh, 2008). Cultural workers may be self-educated or have qualifications from art institutions or universities. This type of labour has heterogeneous characteristics, differentiating it from other types of labour by the nature of the workers' skills and the extent of their talent (Towse, 2010). An increase in skills and abilities may be possible through training and self-training.
Lena (2016) investigated the cultural sector in Turkey between 2009 and 2013. Lena (2016) states that the average of salaries and wages paid to wage-earners across all industry sectors and services was around 20,000 TL (Turkish Lira) annually, compared to an average in the artistic creative sectors of $11.981 \mathrm{TL}$ and in the performing arts of 11.835 TL in 2013 (TurkStat, 2014). Moreover, in Turkey, since cultural activities are included in entertainment activities, the rate of informal economic activity is high due to the high entertainment tax (Lena, 2016). Lena (2016) concluded that the cultural sector has high added value.

The transition between occupations, or having two or more professions at the same time, is common; for example, an actor may also be a musician or may decide to continue his career as a musician. Due to the project-based nature of the industry, 
Table 2: Classification Systems for the Creative Industries derived from Different Models

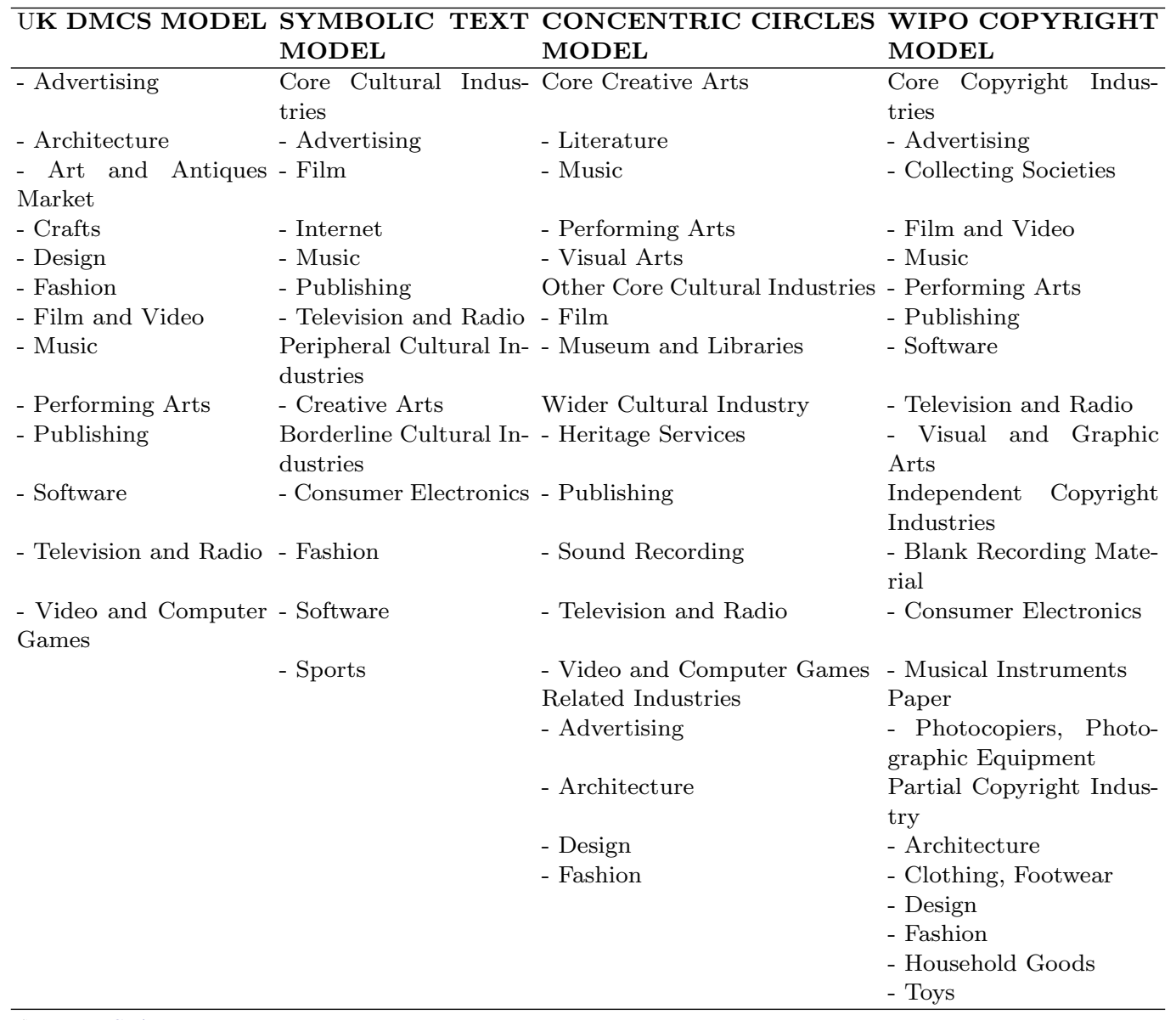

Source: UNCTAD, 2008

a cultural worker may be an employee for one project and an employer for another; for example, a film actor who also owns a theatre.

Atypical work arrangements are evaluated as precarious work (Hesmondhalgh \& Baker, 2011; Nienhueser, 2005) and as representing the erosion of the welfare state (Nienhueser, 2005). Therefore, cultural workers who earn daily rates are precariat, who work with wage flexibility - wage adjustments, particularly downwards; employment flexibility - changes in employment level with no compensation; job flexibility - changes in job structure; and skill flexibility - adjustments in workers' skills (Standing, 2011). Cultural workers are thus at high risk of in-work poverty.

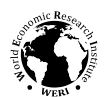

The precarious working conditions of cultural workers were depicted by Hoş (2018), who surveyed 157 actors in Istanbul, Turkey and found that even if the majority of participants agrees on the need to be a trade union member, only a small number of participants are members of a trade union. Furthermore, for the majority, their earnings were not sufficient to earn their keep. Almost half said they were not working in an environment which met occupational health and safety standards and over half were unhappy with their working conditions. Almost all were in areas which lacked legislative regulation on their rights to work and almost none were confident about the future (Hos, 2018).

Cultural workers constitute the supply-side 
dynamics of the sector because they produce cultural goods and services. In Turkey, from 2011 to 2019, cultural employment increased gradually from 522,200 to 668,900 people (Eurostat, 2019b). The cultural employment rate over the same period remained fairly constant at $2.1 \%-2.4 \%$ of the total employment rate in Turkey. Between 2016 and 2019, the rate of cultural workers with a permanent job was around $89 \%-93 \%$, while the rate of cultural workers working in only one job was $97 \%-98 \%$. Moreover, the rate of cultural workers with a full-time job was around $79 \%-87 \%$. The rate of self-employed cultural workers increased over the period from $22 \%$ to $34 \%$. This panorama contradicts the problems indicated by some investigators (Umney \& Kretsos, 2014; Hodgson \& Briand, 2013; Siebert \& Wilson, 2013; Benhamou, 2011; Towse, 2010; Hesmondhalgh, 2008) (see Table 3).

The subsidy, by state or private institutions, of cultural production improves the working conditions of cultural workers. Whether the state or private institutions should support cultural activities and cultural workers is debatable. However, various reasons have been suggested in favour of public support to cultural activities. The state supports local development by helping artistic and cultural consumption; that is to say that these goods and services attract people to cities (Akdede, 2014). Cultural goods are 'merit goods' which have an inherent value for the society (Towse, 2010). Cultural goods and services create an economy and its sector (Horkheimer \& Adorno, 2002), and cultural goods and services can serve as a cultural-ideological state apparatus, used for keeping the masses under control (Althusser, 2014).

Each state contributes to the process of producing works of art through some form of subsidy. Turkey subsidises cultural goods and services through the Ministry of Culture and Tourism whose budget increased from 2009 (1,021 million TL) to $2015(2,297$ million TL), representing an increase of $1 \%$ (from $3.9 \%$ to $4.9 \%$ ) in the total budget. The ministry allocates part of its budget as subsidy for cultural activities. From 2005 until 2009, the subsidy given by the ministry increased from 4 million TL to 15 million TL. However, from 2010 to 2012, this amount decreased to 7 million TL. After that period, the subsidy increased again and had reached 17 million TL in 2015 (Ministry of Culture and Tourism of Turkey, 2015).

NGOs and the private sector are other supporters of cultural activities in Turkey. Many companies sponsor cultural and art foundations, and some cultural and art foundations have tax immunity. For example, the leading sponsor of the Istanbul Foundation for Culture and Arts (IKSV) is the Eczacıbaşı Group, one of the biggest pharmaceutical companies in Turkey. In 2004, the Law on Promotion of Cultural Investments and Initiatives (Num. 5225) came into force in Turkey, allowing those establishments which have a culture investment licence and culture enterprise licence a reduction on income tax withholding and employer's national insurance contributions of between $25 \%$ and $50 \%$ (Revenue Administration of Turkey, 2015).

In addition to the subsidy and support of NGOs and private sectors, another form of supporting the cultural sector is through special social security arrangements. For those artists who earn a daily rate, the Additional Article 6 added to Article 51 of Law No. 6111, as of 1 March 2011, allows artists who work fewer than ten days per month, calculated according to working hours, in areas to be determined by the Ministry of Culture and Tourism to pay their own insurance premiums (Ministry of Culture and Tourism of Turkey, 2012; Social Security Institute of Turkey, 2016). Artists who work fewer than ten days in a month are considered as having paid 30 days social insurance premiums for a temporary period if they pay the premiums at the lowest-earning limit (Caniklioğlu \& 
Table 3: Cultural Employment Indicators of Turkey by Recent Years

\begin{tabular}{lcccc}
\hline Cultural Employment Indicators & $\mathbf{2 0 1 6}$ & $\mathbf{2 0 1 7}$ & $\mathbf{2 0 1 8}$ & $\mathbf{2 0 1 9}$ \\
\hline Cultural Employment (thousands of people) & 613.7 & 647.8 & 662.3 & 668.9 \\
Cultural Employment (\% of total employment) & 2.3 & 2.3 & 2.3 & 2.4 \\
Employees with a Permanent Job (\% of cultural employment) & 91 & 89 & 89 & 93 \\
Self-Employed Persons (\% of cultural employment) & 22 & 31 & 29 & 34 \\
Employed Persons Working Full-Time (\% of cultural employment) & 87 & 81 & 79 & 79 \\
Employed Persons with One Job Only & 98 & 98 & 97 & 98 \\
\hline
\end{tabular}

Source: Eurostat, 2019b

Özkaraca, 2014). If an artist works more than ten days per month, the social security premium has to be paid by the employer (Köme Akpulat, 2017). In 2015, 853 artists benefited from the arrangements for self-paid social insurance premiums (Köme Akpulat, 2017).

In 2015, 34,300 people worked in creative, arts and entertainment activities (Eurostat, 2020a). These activities cover employment in the performing arts, support activities for the performing arts, artistic creation and the operation of arts facilities. According to estimates by the Actors' Trade Union, in Turkey, the number of actors alone in 2015 was around 10,000 (Kadigil, 2017). When comparing this estimate to the number of the artists who benefited from arrangements for self-paid social insurance premiums, the effectiveness of the social security arrangements for artists who earn daily rates may be disputed. Since cultural workers earn lower wages than other sectors (Lena, 2016) and these earnings are not sufficient to earn their keep (Hoş, 2018), cultural workers suffer from not paying their social security premiums despite being allowed to pay the insurance premiums themselves. There is, therefore, a need for a comprehensive change in the social security arrangements for artists.

\section{Data}

This article focuses on people in Turkey who work in a job which contributes to creating culture and investigates the issues surrounding the employment of these cultural workers. It uses data from an online survey of cultural workers in Turkey. Due to the positive relationship between a high level of education and internet usage (Ünver, 2014) and the assumption that cultural workers have a high level of education, the survey was conducted online by the author. It was sent to the labour unions related to the cultural sector, including the Actors' Trade Union of Turkey (Oyuncular Sendikası) and Culture and Arts Workers Union (Kültür ve Sanat Emekçileri Sendikası) in Turkey. 193 cultural workers - including performing artists, architects, graphic designers, publishers, writers, dancers, cultural organisers, art teachers and so on - completed the survey between 22 October and 12 December 2016.

The survey consisted of three sections: job information, personal information and comments on the survey, and 17 questions: job-information-related questions, demographic questions and the comment about the survey. Many questions were asked categorically due to the ease and speed of responses.

Questions related to job information related to the current area of activity (categoric question), the job description (open-ended question), number of years' experience in the cultural sector (open-ended question), the effect of 2008 global economic crisis on the employment status of the participant (categoric question), non-cultural jobs held in the past (open-ended question), employment status - whether self-employed or not (categoric question), whether working in a public or private institution (categoric question), whether working in a subsidised institution (categoric question), full-time or part-time 
contract (categoric question), working hours at home per day (categoric question), contract status (categoric question), total earnings whether from the cultural sector or not (categoric question) and approximate monthly earnings (categoric question) (see Table 3). The monthly earning question was categorised, according to data on minimum wages and cost of living. In 2016, the net minimum monthly wage in Turkey was 1300 TL (Ministry of Labour and Social Security of Turkey, 2016); in October 2016, the minimum monthly cost of living for a single person was $1700 \mathrm{TL}$ and for a family of four was 4558 TL (TURK-İŞ, 2016).

Demographic questions related to age (open question), level of education (categoric question) and gender (categoric question). The survey ended with a question inviting comments about the survey and additional information that the participants could add if they so wanted.

\section{Findings and Discussion}

The survey results are analysed through a descriptive statistics analysis and a nonparametric analysis. The analysis in this section was conducted to understand the trends in cultural employment. Since many questions were categorical, the analysis does not give the exact results, but estimates tendencies.

\subsection{Findings of Descriptive Statistics Analysis and Discussion}

The economic activity area of many participants is in the performing arts with participants also involved in architecture, literature and publishing, organisational jobs, radio and television, technical jobs, visual arts and graphic design. Some participants had more than one occupation. The primary occupations were writer, organiser, director, actor, visual artist, musician, art teacher, editor, architect, dancer and dubbing actor and the most popular secondary occupation of the participants was as an art teacher (see
Table 4).

Many participants had between 6- and 15years' experience in the sector. While approximately two-thirds of participants were not self-employed, fewer than one in five participants work for the public sector. Only one in four participants worked for subsidised cultural institutions while three in four worked for the cultural institutions which had received no subsidy. More than half of the participants worked in a full-time job; almost half worked at home for at least one hour or more per day. Half of the participants worked on a temporary contract while almost one in three had a permanent contract. However, some participants had no contract (see Table 3).

Four of the five participants earned all their income from the cultural sector. Some findings of this study contradict the data from Eurostat (2019b); for example, while Eurostat (2019b) reported that 91\% of cultural workers had a permanent job in 2016 in Turkey, this study found only $35.8 \%$ did so. Furthermore, while Eurostat (2019b) showed that $87 \%$ of cultural workers worked in a fulltime job in 2016, this rate was considerably lower $(58.5 \%)$ in the findings of this survey. While over one in four participants $(26.9 \%)$ declared that they had more than two parttime jobs in 2016, Eurostat (2019b) reported that nearly all cultural workers in Turkey (98\%) had one job only in 2016. However, the findings of this study support the literature (Umney \& Kretsos, 2014; Hodgson \& Briand, 2013; Siebert \& Wilson, 2013; Benhamou, 2011; Towse, 2010; Hesmondhalgh, 2008) (see Table 5).

Other crucial descriptive findings were related to the income of cultural workers. Since the income question was categorical, we calculated the average monthly income of cultural workers by using the minimum level of the category as the base: 0 for $0-1300$ TL; 1300 TL for 1301 TL-1700 TL; 1700 TL for 1701-2500 TL. Although this calculation does not give an exact panorama of the income of the participants, it gives a figure to 
Table 4: Cultural Employment Indicators of Turkey by Recent Years

\begin{tabular}{|c|c|c|c|}
\hline Question & Answer Options & $\begin{array}{c}\% \text { of } \\
\text { Persons }\end{array}$ & $\begin{array}{l}\text { Num. } \\
\text { Persons }\end{array}$ \\
\hline \multirow[t]{3}{*}{ Age } & $18-30$ & $29.50 \%$ & 57 \\
\hline & $31-50$ & $59 \%$ & 114 \\
\hline & $50+$ & $11.40 \%$ & 22 \\
\hline \multirow[t]{2}{*}{ Gender } & Female & $39.40 \%$ & 76 \\
\hline & Male & $60.60 \%$ & 117 \\
\hline \multirow[t]{4}{*}{ Education } & University (bachelor + ) & $44.50 \%$ & 86 \\
\hline & Conservatory or Art Faculty (equal to a bachelor) & $45.60 \%$ & 88 \\
\hline & High School & $8.80 \%$ & 17 \\
\hline & Secondary & $1 \%$ & 2 \\
\hline \multirow[t]{4}{*}{ Experience Year } & $0-5$ & $18.10 \%$ & 35 \\
\hline & $6-15$ & $44.60 \%$ & 86 \\
\hline & $16-25$ & $20.70 \%$ & 40 \\
\hline & $26+$ & $16.60 \%$ & 32 \\
\hline \multirow{6}{*}{$\begin{array}{l}\text { During the Global } \\
\text { Crisis }\end{array}$} & Started to work in the cultural sector & $11.40 \%$ & 22 \\
\hline & Worked for another sector besides my job in the cultural sector & $9.30 \%$ & 18 \\
\hline & Did not change my job & $60.60 \%$ & 117 \\
\hline & Worked for two or more jobs in the cultural sector & $8.80 \%$ & 17 \\
\hline & Student & $9.30 \%$ & 18 \\
\hline & Unemployed & $0.50 \%$ & 1 \\
\hline \multirow{2}{*}{$\begin{array}{l}\text { Having a job in } \\
\text { another sector }\end{array}$} & No & $65.30 \%$ & 126 \\
\hline & Other subsectors of the service sector & $34.70 \%$ & 67 \\
\hline \multirow{2}{*}{$\begin{array}{l}\text { Working for own } \\
\text { job }\end{array}$} & Yes & $30.10 \%$ & 58 \\
\hline & No & $69.90 \%$ & 135 \\
\hline \multirow{2}{*}{$\begin{array}{l}\text { Working for } \\
\text { public or private }\end{array}$} & Public & $22.80 \%$ & 44 \\
\hline & Private & $77.20 \%$ & 149 \\
\hline \multirow{2}{*}{ Having subsidy } & Yes & $25.40 \%$ & 49 \\
\hline & No & $76.60 \%$ & 144 \\
\hline \multirow[t]{4}{*}{ Duration of Work } & Full-Time & $58.50 \%$ & 113 \\
\hline & Part-Time & $11.40 \%$ & 22 \\
\hline & Two or more part-time & $26.90 \%$ & 52 \\
\hline & Unemployed & $3.10 \%$ & 6 \\
\hline \multirow[t]{5}{*}{ Working at Home } & No working at home & $53.40 \%$ & 103 \\
\hline & At least 1 hour per day & $13 \%$ & 25 \\
\hline & At least 2 hours per day & $9.30 \%$ & 18 \\
\hline & At least 3 hours per day & $6.70 \%$ & 13 \\
\hline & At least 4 hours and more per day & $17.60 \%$ & 34 \\
\hline \multirow{3}{*}{ Job Contract Type } & Permanent & $35.80 \%$ & 69 \\
\hline & No contract & $14 \%$ & 27 \\
\hline & Temporary & $50.30 \%$ & 97 \\
\hline \multirow{3}{*}{$\begin{array}{l}\text { All income coming } \\
\text { from cultural } \\
\text { sector }\end{array}$} & Yes & $80.80 \%$ & 156 \\
\hline & No & $17.60 \%$ & 34 \\
\hline & Unemployed & $1.60 \%$ & 3 \\
\hline \multirow{5}{*}{$\begin{array}{l}\text { Average monthly } \\
\text { income }\end{array}$} & $0-1300 \mathrm{TL}$ & $20.70 \%$ & 40 \\
\hline & 1301 TL-1700 TL & $9.80 \%$ & 19 \\
\hline & $1701 \mathrm{TL}-2500 \mathrm{TL}$ & $18.70 \%$ & 36 \\
\hline & 2501 TL- $5000 \mathrm{TL}$ & $36.80 \%$ & 71 \\
\hline & 5000 TL and more & $13 \%$ & 25 \\
\hline
\end{tabular}

Source: The results of the survey which made by the author.

use for comparison with the replies to other questions. This calculation was made in order to identify trends.

One in five participants declared that they earned under the minimum wage (1300 TL) in 2016. Approximately one in ten partic- ipants earned between the minimum wage $(1300 \mathrm{TL})$ and the minimum monthly cost of living for a single person (1700 TL) in the same year. Almost one in five participants earned between the minimum monthly cost of living for a single person and 2500 
Table 5: Comparison of Cultural Employment Data

\begin{tabular}{lcc}
\hline & Findings of This Study & Data of Eurostat for 2016 \\
Employees with Permanent Job & $35.80 \%$ & $91 \%$ \\
Self-Employed & $30.10 \%$ & $22 \%$ \\
Employed Persons Working Full-Time & $58.50 \%$ & $87 \%$ \\
Employed Persons with One Job Only & $70 \%$ & $98 \%$ \\
\hline
\end{tabular}

Source: Eurostat, 2019b

TL. Only approximately one in ten participants earned more than 5000 TL, i.e. more than the minimum monthly cost of living for a family with four persons (4558 TL) in 2016 (see Table 3 ). This confirms the findings of Hoş (2018) and Lena (2016), which indicate that the earnings are not sufficient to earn a living.

A number of studies (Lena, 2016; Benhamou, 2011; Towse, 2010; Hesmondhalgh, 2008) have found that the earnings of cultural workers tend to be lower than in other industries. Although this study did not compare the earnings of cultural workers with those of others, the results of the survey showed that cultural workers in Turkey are at risk of inwork poverty. Almost one in five participants was unable to earn the minimum monthly wage in 2016. The minimum monthly cost of living for a single person was $1700 \mathrm{TL}$ in October 2016, and almost one in three participants did not earn this amount (see Table 4).

The findings show that female cultural workers earned less than male cultural workers. When we compared these results with education level, the findings indicated that this difference represented the earning gap between female and male cultural workers who graduated from art conservatories. At the same time, there was no earning gap between female and male cultural workers who graduated from universities, although these two institutions offer an equal level of education. However, these findings are vital in highlighting the importance of detailed research on the earning gap between men and women in Turkey in the future (see Figure Figure 2).

The relationship between age and income was another descriptive finding of the survey. The lowest average income occurs in the

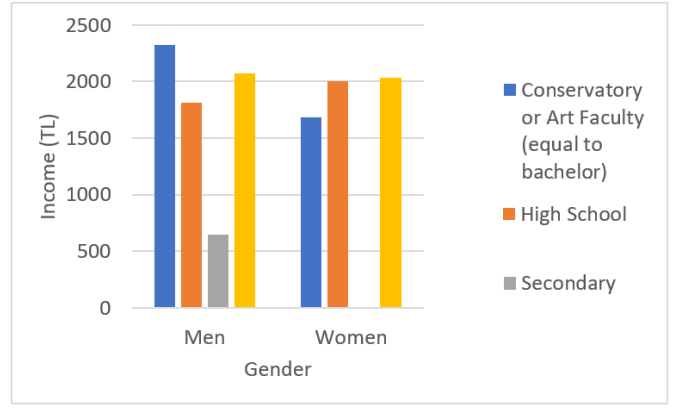

Figure 2: Average Monthly Income Level by Gender

18-30 age range. Although experience has a positive impact on income, average monthly income increases until 50 years, after which it decreases. Cultural workers in Turkey are at risk of poverty in old age (see Figure 3).

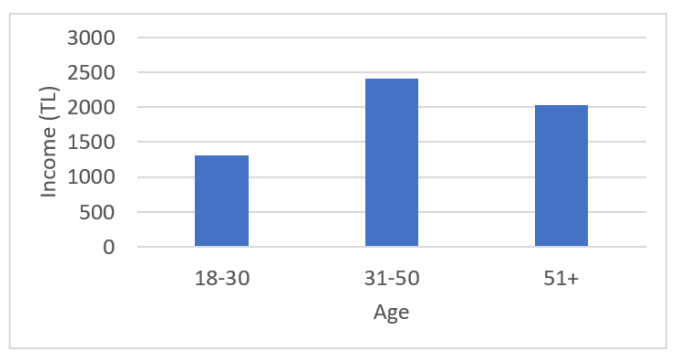

Figure 3: Average Monthly Income Level by Age

Contract types also affect the income of cultural workers. Those who do not have a contract or have temporary contracts tend to earn less than cultural workers who have permanent contracts (see Figure 4).

Whether a cultural institution receives state subsidy affects the income of cultural workers: salaries at subsidised institutions tend to be higher than others. However, being selfemployed in the cultural sector may have a positive effect on income (see Figure 5 and Figure 6). 


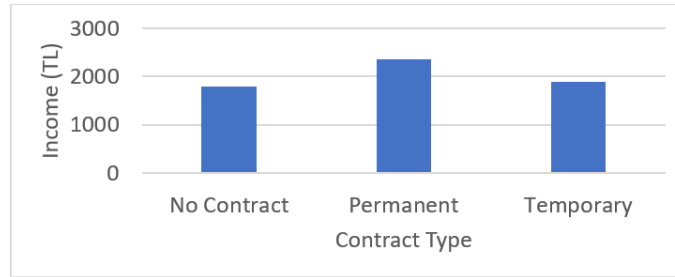

Figure 4: Average Monthly Income Level by Contract Type

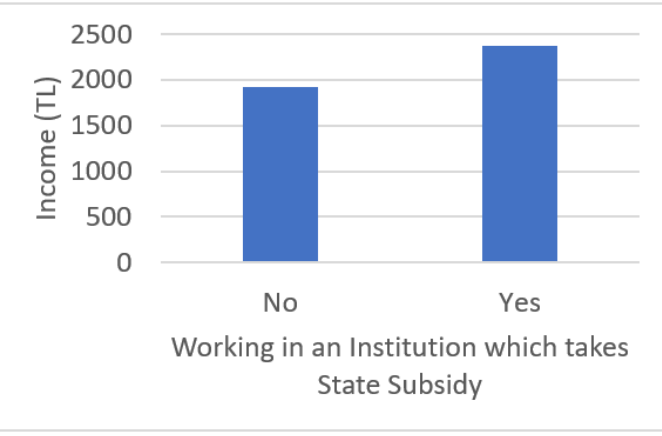

Figure 5: Average Monthly Income Level by Working in an Institution with State Subsidy

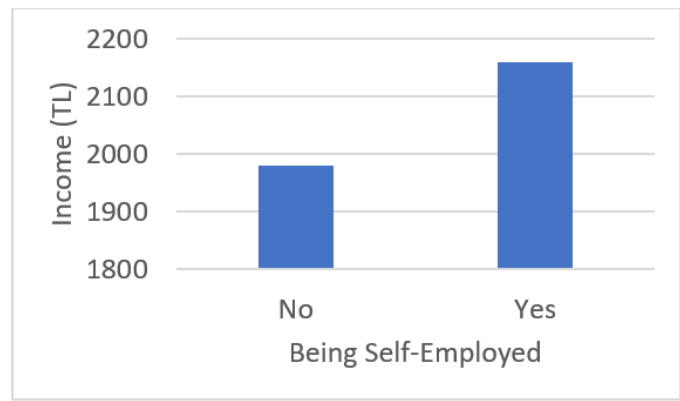

Figure 6: Average Monthly Income Level by Being Self-Employed

Another important finding of this study is that many participants did not change job during the 2008 global economic crisis. When the resilience of the cultural sector to the economic crisis is measured by the condition of having a job or not changing job, the cultural sector is found to be resilient to the economic crisis. This result, for Turkey, is consistent with the finding that the cultural sector was resilient to the economic crisis (UNDP, 2010). The transience between occupations may explain this resilience: holding multiple occupations may increase the chance of finding a job even during the economic crisis. Another reason may be that almost half the participants had more than 5 years' experience in 2008 and this greater experience may have been an advantage in remaining in work even during the economic crisis. However, it is essential to query the quality of the job; having a job does not mean having an appropriate job.

\subsection{Findings of Non-Parametric Sta- tistical Analysis and Discussion}

The statistical analysis of the survey clarified four crucial areas: the relationship between the income of cultural workers and working in a subsidised institution; the relationship between the income of cultural workers and contract type; the relationship between the income of cultural workers and self-employment; and the relationship between working at home and being selfemployed. Since the data were categorical, the statistical analysis was conducted using the Chi-Square test, which allows us to see whether there is a relationship between two variables but cannot indicate the direction and the strength of this relationship.

The descriptive analysis supported the statistical analysis in this study. When we compared the situation of the participants (i.e. whether they worked in an institution in receipt of subsidy) with the calculation of their average monthly income, the findings showed that the participants who worked in a subsidised institution earned more than the participants who did not (see Table 6). This may be a positive effect of the increase in subsidy given by the Ministry of Culture and Tourism from 2005 to 2015 (Ministry of Culture and Tourism of Turkey, 2015).

The descriptive analysis also showed that the participants who had permanent contracts earned more than those who had temporary contracts and indicated that cultural workers with no contract earned the lowest average monthly income among them all. This descriptive finding supported the findings of the statistical analysis, which showed the relationship between the income of cultural workers and the type of job contract (see Ta- 
Table 6: Relationship between the Income of Cultural Workers and Working in an Institution which Takes Subsidy

\begin{tabular}{lccc}
\hline & Value & df & $\begin{array}{c}\text { Asymp. Sig. } \\
\text { (2-sided) }\end{array}$ \\
\hline $\begin{array}{l}\text { Pearson Chi- } \\
\text { Square }\end{array}$ & $10.194^{a}$ & 4 & 0.037 \\
$\begin{array}{l}\text { Likelihood Ratio } \\
\text { Linear-by-Linear }\end{array}$ & 11.782 & 4 & 0.019 \\
$\begin{array}{l}\text { Association } \\
\text { N of Valid Cases }\end{array}$ & 191 & 1 & 0.012 \\
$\begin{array}{l}\text { a. 1 cells (10.0\%) have expected count less than 5. The } \\
\text { minimum expected count is 4.77. }\end{array}$
\end{tabular}

ble 7) and emphasises the importance of having a job contract.

- Self-employed participants earned more

Table 7: Relationship between the Income of Cultural Workers and Working in an Institution which Takes Subsidy

\begin{tabular}{lccc}
\hline & Value & df & $\begin{array}{c}\text { Asymp. Sig. } \\
\text { (2-sided) }\end{array}$ \\
\hline $\begin{array}{l}\text { Pearson Chi- } \\
\text { Square }\end{array}$ & $19.419^{a}$ & 8 & .013 \\
$\begin{array}{l}\text { Likelihood Ratio } \\
\text { Linear-by-Linear }\end{array}$ & 19.529 & 8 & .012 \\
$\begin{array}{l}\text { Association } \\
\text { N of Valid Cases }\end{array}$ & 191 & 1 & .005 \\
$\begin{array}{l}\text { a. 2 cells (13.3\%) have expected count less than 5. The } \\
\text { minimum expected count is 2.69. }\end{array}$
\end{tabular}

than participants who were not selfemployed, from the calculation of the average monthly income of the participants. The statistical analysis also confirmed the relationship between the income of the participants and their self-employed status (see Table 8). The findings of this study indi-

Table 8: Relationship between the Income of Cultural Workers and Working in an Institution which Takes Subsidy

\begin{tabular}{lccc}
\hline & Value & df & $\begin{array}{c}\text { Asymp. Sig. } \\
(2-\text {-sided })\end{array}$ \\
\hline $\begin{array}{l}\text { Pearson Chi- } \\
\text { Square }\end{array}$ & $11.363^{a}$ & 4 & .023 \\
$\begin{array}{l}\text { Likelihood Ratio } \\
\text { Linear-by-Linear }\end{array}$ & 11.012 & 4 & .026 \\
$\begin{array}{l}\text { Association } \\
\text { N of Valid Cases }\end{array}$ & 193 & 1 & .004 \\
$\begin{array}{l}\text { a. 1 cells (10.0\%) have expected count less than 5. The } \\
\text { minimum expected count is 3.91 }\end{array}$
\end{tabular}

cate that the working conditions of cultural workers present many challenges. In com- mon with Hos (2018), this study suggests that cultural workers need more comprehensive policies to be implemented to improve their working conditions.

Since categorical questions were used for ease and speed in replying, the statistical findings were not meticulous, because the ChiSquare test gives no information about the size and direction of the relationship between the variables. However, these findings were still vital because they give an idea of the relationship between the variables. Moreover, the descriptive analysis of the survey supported the findings of the statistical analysis, indicating the need for more detailed studies. Therefore, this study agrees with Şen (2017), who highlighted the lack of systematic studies about cultural employment in Turkey.

\section{Conclusion}

Culture gives a form to human behaviour and relationships through creativity, symbolic messages and intellectuality. Therefore, culture is everywhere, at every moment in human life. Humans produce culture from objects, even their bodies. This process has transformed into an industry today, and it has created an industry. Although the definitions of this industry differ, including creative industry, cultural industry and creative and cultural industries, this study embraces the term 'cultural industry', which focuses on producing culture. The cultural industry of Turkey has a comparative advantage because the export of cultural goods is greater than the import. However, in recent years, Turkey has been losing this advantage. Therefore, to keep this advantage, as the findings of this article show that subsidy has a positive effect on the income of cultural workers, Turkey may increase subsidies for cultural workers. Cultural workers, however, should be precisely defined. Although there is a focus on initial creative artists (such as writers, visual artists, craftspeople and composers) and performing artists (such as actors, dancers and musicians) in defining cultural workers, this definition omits the non-artistic workers who 
contribute to producing culture. A broader definition includes three types of workers: those who have artistic occupations within the cultural industry, those who do not have any artistic occupation but work in the cultural industry, and those who have artistic occupations but work outside the cultural industry. However, there is still a need to identify cultural workers through a more concrete measurement. The model used in Finland to identify cultural workers might be adopted in Turkey.

Cultural employment carries atypical employment conditions such as freelance or self-employed work, multiple jobs, irregular, short-term jobs, project-based jobs, a portfolio career path, income insecurity and very little job protection, an uncertain career path, a higher likelihood of unpaid work and lower earnings than in other industries. These poor working conditions are known as precarity, flexible working without job security. This article uses data from an online survey of cultural workers conducted in Turkey in November and December 2016. The survey consists of three parts: questions related to job information, demographic questions and comments about the survey. Categorical questions were chosen primarily due to the ease and speed of replying. The income question was also categorical, taking into consideration hunger and poverty thresholds.

The findings of the survey agree with the literature on a large scale. The main findings are that cultural workers in Turkey are at risk of in-work poverty due to their low earnings, and this risk tends to increase in oldage; there is an earning gap between female and male cultural workers; cultural workers who do not have a contract earn the lowest average monthly income compared to those with a temporary or a permanent contract; the income of cultural workers is statistically related to whether they work in a subsidised institution, their contract type and whether they are self-employed; and the rate of working at home among cultural workers is high, and this situation is statistically related to being self-employed.

The findings show that cultural workers face in-work poverty although they serve an industry which has a comparative advantage in terms of trade. This study highlights the need for systematic studies about cultural employment and the implementation of comprehensive policies to protect the rights of cultural workers in Turkey. This article recommends increasing the studies collecting data about cultural employment and identifying cultural workers through concrete measurements. To this end, the creation of an umbrella organisation might be helpful, and this umbrella organisation could develop emergency action plans for disadvantaged cultural workers such as women and older people.

\section{References}

Abadan-Unat, N. (1983). Kitle İetişim ve kültür. Illetişim teknolojisindeki gelişmelerin ulusal kültürlere ve basma etkisi. İstanbul: Türkiye UNESCO Milli Komisyonu Basın Yayın Genel Müdürlüğü.

Çaha, O. (2012). Türkiye'de meslek kuruluşları: Katılım, Şeffaflık ve siyasî duruş sorunu. Liberal Düşüce, 17(67), 97-122. https://dergipark . org.tr/en/pub/liberal/issue/48167/609480.

Akdede, S. H. (2014). Devlet sanat İlişkisi sanatın politik ekonomisi. Ankara: Efil Yayınevi.

Althusser, L. (2014). İdeoloji ve devletin İdeolojik aygıtları. İstanbul: İthaki Yayınları.

Artun, A. (2014). Sunuş/sanat emeği. In A. Artun (Ed.), Sanat emeği. kültür İş̧ileri ve prekarite (pp. 11-30). İstanbul: İletişim Yayıncılık.

Benhamou, F. (2011). Artists' labour markets. In R. Towse \& A. Khakee (Eds.), A handbook of cultural economics (pp. 53-59). Cheltenham: Edward Elgar Publishing.

Benjamin, W. (2008). The work of art in the age of its technological reproducibility and other writings on media (E. Jephcott, R. Livingstone, \& H. Eiland, Trans.). London: The Belknap Press of Harward University Press.

Caniklioğlu, N., \& Özkaraca, E. (2014). Sanatçların sosyal güvenliği. İstanbul Üniversitesi Hukuk Fakültesi Mecmuası, 72(2), 637664. https://dergipark.org.tr/en/pub/iuhfm/ issue/9190/115359.

Casey, B. (1999). Employment and skills in cultural sector: Some reflexions on the european commission paper 'culture, cultural industries and 
employment'. In A. Elimeier \& V. Ratzenböck (Eds.), Cultural competence: New technologies, culture $\& 3$ employment (pp. 40-47). Vienna: Österreichische Kulturdokumentation.

Cetiz, F. (2017). Yaratıcı ekonomiler bağlamında ortak Çalışma alanlarının gelişimi, 21. yy'da $\dot{I}_{s ̧}$ ve Çalışma hayatına etkisi: Istanbul Örneği (Unpublished Master's Thesis). İstanbul: Kadir Has Üniversitesi. https://tez.yok.gov.tr/UlusalTezMerkezi/ TezGoster?key=q3-d9QtLoVA20MExHSkJpZJe J -qHnD9X jePpSoZ2vB1TEfxiZQ9Xn98ABGcMb6if.

Constitution of The Republic of Turkey. (1982). Retrieved from. Ankara, Turkey. https://www.tbmm .gov.tr/anayasa/anayasa_2011.pdf.

Demir, E. M. (2018). Başkent Üniversitesinde yaratıcı kültür endüstrileri araştırma ve uygulama merkezi araştırmacısı dr erhan m. demir ile söyleşi. Hacettepe Üniversitesi İletişim Fakültesi Kültürel Çalışmalar Dergisi, 5(2), 310-319. doi:10.17572/mj2018.2.310319

Eagleton, T. (2016). Culture. New Haven: Yale University Press.

Eikhof, D. R., \& York, C. (2016). 'it's a tough drug to kick': A woman's career in broadcasting. Work, Employment and Society, 30(1), 152-161. doi:10.1177/0950017015601859

Şen, F. (2017). Türkiye'de kültür ekonomisinin boyutları. Ankara: Kaynak Yayınları.

Erataş, F., Alptekin, V., \& Uysal, D. (2013). Türkiye'de kültür ekonomisinin gelişimine yerel bir bakış. Muş Alparslan Üniversitesi Sosyal Bilimler Dergisi, 1(2), 25-47. https://dergipark .org.tr/en/pub/anemon/issue/1834/22344.

Erkayhan, . (2015). Yaratıcı endüstriler ve díjital gelecek stratejileri. E-Journal of Intermedia, 2(2), 411-423. http:// intermedia.ticaret.edu.tr/index.php/ intermedia/article/view/36/32.

Eurofound. (2017). Atypical work-european observatory of working life (Web Article). Dublin: European Foundation for the Improvement of Living and Working Conditions. https:// www. eurof ound . europa.eu/observatories/ eurwork/industrial-relations-dictionary/ atypical-work.

Eurostat. (2019a). Cultural employment by nace rev. 2 activity (Statistics). Luxemburg: Eurostat, the statistical office of the European Union. https://data.europa.eu/euodp/ en/data/dataset/btT7MS3Es7ZlEerEPerOUQ.

Eurostat. (2019b). Cultural statistics - 2019 edition statistical books. Luxembourg: Eurostat.

Eurostat. (2020a). Cultural employment by nace rev. 2 activity (Statistics). Luxemburg: Eurostat, the statistical office of the European Union. https://data.europa.eu/euodp/ en/data/dataset/btT7MS3Es7Z1EerEPerOUQ.

Eurostat. (2020b). Culture statistics (Statistics). Luxemburg: Eurostat, the statistical office of the European Union. https://ec.europa.eu/ eurostat/web/culture/data/database.
Feist, A. (2000). Cultural employment in europe. Strasbourg: Council of Europe.

Galloway, S., \& Dunlop, S. (2007). A critique of definitions of the cultural and creative industries in public policy. International Journal of Cultural Policy, 13(1), 17-31. doi:10.1080/10286630701201657

Gerşil, G., \& Aracı, M. (2006). Küreselleşme sürecinde türk İşçi sendikacıllğ̆ ve yaşanan Örgütlenme sorunu. Muğla Üniversitesi Sosyal Bilimler Enstitüsü Dergisi, 16, 1731. https://dergipark.org.tr/en/pub/musbed/ issue/23524/250643.

Hardt, M. (1999). Affective labor. boundary 2, 26(2), 89-100.

Hardt, M., \& Negri, A. (2000a). Empire. Cambridge: Harvard University Press.

Hardt, M., \& Negri, A. (2000b). Multitude: War and democracy in the age of empire. New York: The Penguin Press.

Hesmondhalgh, D. (2008). Cultural and creative industries. In T. Bennett \& J. Frow (Eds.), The sage handbook of cultural analysis (pp. 553-569). London: SAGE Publications.

Hesmondhalgh, D., \& Baker, S. (2011). Creative labour: Media work in three cultural industries. Oxon and New York: Routledge.

Highmore, B. (2016). Culture. Oxon and New York: Routledge.

Hoş, Z. (2018). $\quad \dot{I}_{\xi ̧}$ ve sosyal güvenlik mevzuatı bakımından sanatçı hakları: Oyuncular Üzerine bir alan araştırması (Unpublished $\mathrm{PhD}$ Thesis). Eskişehir: Anadolu University. https://tez.yok .gov.tr/UlusalTezMerkezi/TezGoster?key= hcgrYffRbz0Z44UJEuLtwR9nMDdlQU7cqxR9Ajr2CnY 5VJDzFnPALMkfCzzljrP.

Hocaoğlu, D. (2015). Yaratıcı endüstrilerin yerel ekonomilerdeki Önemi ve tasarımı bu endüstrilere katkısı. Planlama, 25(3), 189-194. doi:10.5505/planlama.2016.55265

Hochschild, A. R. (1983). The managed heart: Commercialization of human feeling. Berkeley: University of California Press.

Hodgson, D., \& Briand, L. (2013). Controlling the uncontrollable: 'agile' teams and illusions of autonomy in creative work. Work, Employment and Society, 27(2), 308-325. doi:10.1177/0950017012460315

Horkheimer, M., \& Adorno, T. W. (2002). Dialectic of enlightenment (E. G. S. Noerr \& E. Jephcott, Trans.). Stanford: Stanford University Press.

Huizinga, J. (2006). Homo ludens oyunun toplumsal Işlevi Üzerine bir deneme (M. A. Kılıçbay, Trans.). İstanbul: Ayrıntı Yayınları.

Şimşek, G., \& Güven, A. (2015). Yaratici sektörlerde türkiye için yeni bir İvme: Midwood İstanbul film stüdyo kompleksi. Uluslararası Sosyal Araştırmalar Dergisi, 10(51), 1131-1146. doi:10.17719/jisr.2017.1844

ITUC. (2016). Ituc global rights index 2016 (Report). Brussels: International Trade Union Confederation. https://www.ituc-csi.org/ituc -global-rights-index-2016. 
ITUC. (2018). Ituc global rights index 2018 (Report). Brussels: International Trade Union Confederation. https://www.ituc-csi.org/IMG/ pdf/ituc-global-rights-index-2018-en-final -2 .pdf.

Jenks, C. (1993). Culture. key ideas. New York: Routledge.

Kadıgil, S. (2017). Uygulamada karşılaşılan sorunlar ve Çözüm Önerileri. In G. Alpagut (Ed.), Sahne ve perde Çalışanlarının hukuki sorunları (pp. 135-144). İstanbul: Aristo.

Karaca, A. (2017). Sahne ve perde Calışanlarının İş İlişkileri ve Çalışma koşulları hakkında tespitler. In G. Alpagut (Ed.), Sahne ve perde Çalışanlarının hukuki sorunları (pp. 7588). İstanbul: Aristo.

Kaymas, S. (2019). Türk dünyasında kültür ve yaratıcı endüstri yönetişimi Üzerine bir değerlendirme. bilig - Türk Dünyası Sosyal Bilimler Dergisi, 90, 215-243. doi:10.12995/bilig.9010

Kepenek, E. B. (2015). Yaratıcı endüstrileri ve girişimci Üniversiteler İlişkisi: Dijital oyun sektörü Üzerinden bir İnceleme. Politik Ekonomik Kuram, 4(1), 141-169. doi:10.30586/pek.735020

Köme Akpulat, A. (2017). Sanatçıların sosyal sigortalığı. In G. Alpagut (Ed.), Sahne ve perde Çalı̧̧anlarının hukuki sorunları (pp. 96-134). Istanbul: Aristo.

Kroeber, A. L., \& Kluckhohn, C. (1952). Culture. a critical review of concepts and definitions. Cambridge: Harward University.

Lazzarato, M. (1996). Immaterial labor. In P. Virno \& M. Hardt (Eds.), Radical thought in italy: A potential politics (pp. 133-150). Mineapolis: University of Minnesota Press.

Lena, F. (2016). Türkiye'de kültürel sektörlerin Ülke ekonomisine katkısı. İstanbul: Bilgi Üniversitesi Yaymları.

Macionis, J. J. (2010). Sociology. Boston: Prentice Hall.

Malinowski, B. (1960). A scientific theory of culture and other essays. New York: University of North Carolina Press.

Ministry of Culture and Tourism of Turkey. (2012). Genelge 2012/8 (sanatçı olarak kısmi süreli Çalışanlara ait giriş bildirgesi onayına Iliş̧kin usul ve esaslar) (Public Mandate No. 301). Ankara: T.C. Kültür ve Turizm Bakanlığı. https://teftis.ktb.gov.tr/ TR-264340/genelge-20128-sanatci-olarak -kismi-sureli-calisanlara-a-.html.

Ministry of Culture and Tourism of Turkey. (2015). 2015 yıl İdare faaliyet raporu (Report No. 301). Ankara: T.C. Kültür ve Turizm Bakanlı̆̆1. https://sgb.ktb.gov.tr/TR-158779/ 2015-yili-idare-faaliyet-raporu.html.

Ministry of Labour and Social Security of Turkey. (2016). Asgari Ücretin net hesabr ve İsverene maliyeti (Statistics). Ankara: T.C. Çalışma ve Sosyal Güvenlik Bakanlığı.
http://www.csgb.gov.tr/home/Contents/ Istatistikler/AsgariUcret.

Mitchell, R., \& Karttunen, S. (1992). Why and how to define an artist: Types of definition and their implications for empirical research results. In R. Towse \& A. Khakee (Eds.), Cultural economics (pp. 175-186). Heidelberg: Springer-Verlag.

Mitropoulos, A. (2014). Güvence-siz? (E. Gen, Trans.). In A. Artun (Ed.), Sanat emeği: Kültür İş̧ileri ve prekarite (pp. 87-99). İstanbul: Iletişim Yayınları.

Nienhueser, W. (2005). Flexible work = atypical work $=$ precarious work?: Introduction to the special issue. Management Revue, 16(3), 299303. http://www. jstor.org/stable/41782048.

Ünver, H. (2014). Explaining education level and internet penetration by economic reasoning worldwide analysis from 2000 through 2010. International Journal for Infonomics (IJI), 7(12), 898-912. https://infonomics-society.org/ wp-content/uploads/iji/published-papers/ volume-7-2014/Explaining-Education-Level -and-Internet-Penetration.pdf.

O'Connor, J. (2011). The cultural and creative industries: A critical history. EKONOMIAZ. Revista vasca de Economía, 78(03), 24-47. https://www.researchgate.net/ profile/Justin_Oconnor2/publication/ 241757041_The_Cultural_and_Creative _Industries_A_Critical_History/links/ 5a610b880f7e9b6b8fd3e985/The-Cultural-and -Creative-Industries-A-Critical-History.

OECD. (2019). Trade union (Statistics). Paris: Organisation for Economic Co-Operation and Development. https://stats.oecd.org/Index . aspx?DataSetCode=TUD\#.

Peksan, S., \& Tosun, F. (2014). Sanatçıların sosyal haklara ulaşımındaki güçlükler. Çalışma ve Toplum, 42(3), 207-230. https://www.calismatoplum.org/Content/ pdf/calisma-toplum-1547-4eaa5f43.pdf.

Primorac, J. (2014). The position and perspectives of cultural and creative industries in southeastern europe. Medijska Istraživanja, 20(1), 45-64. https://hrcak.srce.hr/126390.

Revenue Administration of Turkey. (2015). K5225 sayılı kültür yatırımlarını ve girişimlerini teşvik kanunu ile getirilen vergisel teşvikler (Statistics). Ankara: Gelir Dairesi Başkanlığı. http://www.gib.gov.tr/yardim-ve-kaynaklar/ yatirimlarda-vergisel-tesvikler/ 1-kanunlarina-gore-vergisel-tesvikler/ $\mathrm{k}-5225$.

Siebert, S., \& Wilson, F. (2013). All work and no pay: Consequences of unpaid work in the creative industries. Work, Employment and Society, 27(4), 711-721. doi:10.1177/0950017012474708

Social Security Institute of Turkey. (2016). Sanatçıların sigortalılığı (Web Article). Ankara: Sosyal Güvenlik Kurumu. http:// www.sgk.gov.tr/wps/portal/sgk/tr/calisan/ calisan/sanatcilarin_sigortaliligi. 
Standing, G. (2011). The precariat: The new dangerous class. London: Bloomsbury Academic.

Throsby, D. (1992). Artists as workers. In R. Towse \& A. Khakee (Eds.), Cultural economics (pp. 201-208). Heidelberg: Springer-Verlag.

Throsby, D. (2008). From cultural to creative industries: the specific characteristics of the creative industries. In Troisième journées d'economie de la culture: Nouvelles frontières de l'economie de la culture (pp. 1-8). Paris.

Tischler, H. (2011). Introduction to sociology. Belmont: Wadsworth, Cengage Learning.

Towse, R. (2010). A textbook of cultural economics. Cambridge: Cambridge University Press.

TURK-İS. (2016). Ekim 2016 açlık ve yoksulluk sınırı. retrieved november (Report). Ankara: Türkiye İşçi Sendikaları Konfederasyonu. http://www.turkis.org.tr/EKIM-2016 -ACLIK-ve-YOKSULLUK-SINIRI-d1260.

TurkStat. (2014). Kültür Istatistikleri 2013. Ankara: Türkiye İstatistik Kurumu Matbaası.

Umney, C., \& Kretsos, L. (2014). Creative labour and collective interaction: the working lives of young jazz musicians in london. Work, Employment and Society, 28(4), 571-588. doi:10.1177/0950017013491452

UNCTAD. (2008). Creative economy report. Geneva: United Nations Conference on Trade and Development.

UNDP. (2010). Creative economy: A feasible development option. New York: United Nations Development Programme.

Van Liemt, G. (2014). Employment relationships in arts and culture (Working Paper No. 301). Geneva: International Labour Office. http://www.oit.org/wcmsp5/groups/ public/---ed_dialogue/---sector/documents/ publication/wcms_249913.pdf.

Yörük, E. (2018). Yaratıcı endüstriler politikaları ve yaratıcı emek Üzerine bir tartışma. Emek Araştırma Dergisi (GEAD), 9(13), 4972. http://emekarastirma.org/uploads/dergi/ 2936.pdf 